OPEN ACCESS

Edited by:

Hannelore Waska,

University of Oldenburg, Germany

Reviewed by:

William Patrick Gilhooly III, Indiana University-Purdue University Indianapolis, United States

Vincent Post

Federal Institute For Geosciences and Natural Resources, Germany

*Correspondence:

Willard S. Moore

moore@geol.sc.edu

Specialty section:

This article was submitted to

Biogeoscience,

a section of the journal

Frontiers in Earth Science

Received: 30 August 2020

Accepted: 18 March 2021

Published: 08 April 2021

Citation:

Moore WS and Joye SB (2021)

Saltwater Intrusion and Submarine Groundwater Discharge: Acceleration

of Biogeochemical Reactions

in Changing Coastal Aquifers.

Front. Earth Sci. 9:600710.

doi: 10.3389/feart.2021.600710

\section{Saltwater Intrusion and Submarine Groundwater Discharge: Acceleration of Biogeochemical Reactions in Changing Coastal Aquifers}

\author{
Willard S. Moore ${ }^{1 *}$ and Samantha B. Joye ${ }^{2}$ \\ ${ }^{1}$ School of the Earth, Ocean and Environment, College of Arts and Sciences, University of South Carolina, Columbia, SC, \\ United States, ${ }^{2}$ Department of Marine Sciences, Franklin College of Arts and Sciences, University of Georgia, Athens, GA, \\ United States
}

Intrusion of saltwater into freshwater coastal aquifers poisons an essential resource. Such intrusions are occurring along coastlines worldwide due largely to the overpumping of freshwater and sea level rise. Saltwater intrusion impacts drinking water, agriculture and industry, and causes profound changes in the biogeochemistry of the affected aquifers, the dynamic systems called subterranean estuaries. Subterranean estuaries receive freshwater from land and saltwater from the ocean and expose this fluid mixture to intense biogeochemical dynamics as it interacts with the aquifer and aquiclude solids. Increased saltwater intrusion alters the ionic strength and oxidative capacity of these systems, resulting in elevated concentrations of certain chemical species in the groundwater, which flows from subterranean estuaries into the ocean as submarine groundwater discharge (SGD). These highly altered fluids are enriched in nutrients, carbon, trace gases, sulfide, metals, and radionuclides. Seawater intrusion expands the subterranean estuary. Climate change amplifies sea level variations on short and seasonal time scales. These changes may result in higher SGD fluxes, further accelerating release of nutrients and thus promoting biological productivity in nutrientdepleted waters. But this process may also adversely affect the environment and alter the local ecology. Research on saltwater intrusion and SGD has largely been undertaken by different groups. We demonstrate that these two processes are linked in ways that neither group has articulated effectively to date.

\footnotetext{
Keywords: saltwater intrusion, submarine groundwater discharge, subterranean estuary, coastal aquifer, nutrient dynamics, sulfate reduction
}

\section{INTRODUCTION: SALTWATER INTRUSION AND SUBMARINE GROUNDWATER DISCHARGE}

Saltwater intrusion, the landward excursion of seawater in coastal aquifers, has been recognized since the 19th century as water in impacted aquifers became non-potable (Werner and Simmons, 2009). Extensive efforts have aimed to understand and eliminate this problem; nevertheless, groundwater salinization is accelerating along many coastlines. The primary cause of saltwater 
intrusion is over-pumping of fresh groundwater from coastal aquifers, thereby reducing the hydrostatic pressure and drawing saltwater into the aquifer. The source of the saltwater may be the ocean or relic saltwater residing deeper in the aquifer or in an adjacent aquifer. As little as $1 \%$ seawater will render groundwater non-potable by taste.

Besides over-pumping, other factors exacerbate saltwater intrusion. Sea level rise alters the hydrostatic balance between the aquifer and the coastal ocean. A massive sea level rise at the end of the last glacial period inundated continental shelves worldwide and drove seawater into coastal aquifers. On a coastal plain with a slope of $1: 1000$, a $10 \mathrm{~cm}$ rise in sea level can lead to a $100 \mathrm{~m}$ inland intrusion of seawater into the aquifer (Werner and Simmons, 2009). Future sea level rise of a meter or more during this century (Hansen et al., 2016) will further intensify the expansion. Processes that channel precipitation into surface runoff rather than groundwater recharge also exacerbate saltwater intrusion. These processes include canal construction to drain freshwater coastal wetlands, sewers to drain golf courses, and the replacement of permeable surfaces with impermeable surfaces linked to sewers, e.g., roads, parking lots, buildings. Additionally, pier and bridge construction, installation of pilings for buildings, and harbor dredging may breach confining layers above coastal aquifers, allowing seawater to invade the aquifer. These human impacts are significantly altering coastal aquifers across the globe, accelerating saltwater intrusion at unprecedented-and largely unrealized-rates (Werner et al., 2013).

Most of the concern with saltwater intrusion focuses on the universal needs of local populations for potable water as well as demands from industry and agriculture for freshwater. As such they focus on sodium and chloride. Here we examine additional consequences of saltwater intrusion into coastal aquifers, namely desorption of adsorbed ions and the plethora of reactions linked to sulfate reduction.

During the past 25 years, considerable research, (summarized by Burnett et al., 2003; Moore, 2010; Jiao and Post, 2019), has advanced knowledge of the regulation, dynamics, and biogeochemical importance of submarine groundwater discharge (SGD). Bratton (2010) described three scales of SGD including nearshore and embayment scale processes as well as discharge throughout the continental shelf. Though SGD and seawater intrusion may seem intuitively to be opposing processes, Taniguchi et al. (2006) recognized that they are, in fact, complementary. Much of the seawater that intrudes into the aquifer actively circulates between the aquifer and the ocean in response to periodic forcing functions, including tides (Moore et al., 2002; Robinson et al., 2007), storms (Wilson et al., 2011), persistent wind events (George et al., 2020), seasonality in precipitation and recharge (Michael et al., 2005), seasonality in sea level (Wahl et al., 2014), and seasonality in freshwater withdrawal (Moore, 1999). The water discharging as SGD has a radically different chemical signature compared to the fresh or saltwater that entered the aquifer (Moore, 1999, 2010). Thus, SGD is not simply fresh groundwater flowing into the ocean; instead, it represents a mixture of saltwater and freshwater containing the byproducts of intense biogeochemical reactions between the fluids and aquifer solids.

\section{SUBTERRANEAN ESTUARIES}

To emphasize the processes of saltwater-freshwater circulation and reactions with aquifer solids, these affected coastal aquifers are called subterranean estuaries (Moore, 1999). The concept of subterranean estuaries frames coastal aquifers as a dynamic biogeochemical analog of surface estuaries, where fresh water, particles and ocean water mix, fueling a plethora of biogeochemical dynamics and generating unique biogeochemical signatures. Fluids within subterranean estuaries become enriched in the products of biogeochemical reactions, including nutrients, carbon (dissolved inorganic and organic), hydrogen sulfide and other trace gasses, reduced metals, and radionuclides (Moore, 2010). Through SGD, these dramatically altered fluids are delivered to surface estuaries and the coastal ocean. Well over 100 studies focusing on the role of SGD in supplying nutrients, carbon, and metals to coastal waters have concluded, in large part, that SGD is a more important source of these materials than local rivers (Moore, 2010).

Moore (1999) coined the term "subterranean estuary" to help explain why the circulation of seawater through coastal aquifers was important. At the time many scientists equated SGD with subsurface flow of freshwater into the ocean. In a comment to Moore (1996); Younger (1996) argued that if SGWD (now called SGD) is largely of marine origin, its input to the ocean is "unremarkable." Because there is a vast estuarine literature, it is easy to convey why the circulation of brackish water within a surface estuary is important: It creates unique environments for a wide array of organisms and accelerates biogeochemical processes. By tapping into the estuarine literature, Moore (1999) was able to convey the importance of circulation through the subterranean estuary and the reactions of salty groundwater with the solids in the system, thereby creating unique environments rich in nutrients, carbon and metals. This concept drew the attention of coastal scientists and many chose to explore this system.

Some have argued that there is no need for the term "subterranean estuary" because this term is already described by hydrologists as a "transition zone" within a coastal aquifer (Jiao and Post, 2019). They consider the term "confusing and misleading" by wrongly stating that subterranean estuary means "subsurface river mouth." The confusion is due to their misunderstanding of the term "estuary," which they claim must be located at a river mouth. This is not the case. The most widely used definition of estuary by scientists who study them is: " $A$ semi-enclosed coastal body of water which has a free connection with the open sea and within which seawater is measurably diluted with fresh water derived from land drainage" (Pritchard, 1967). Thus, a coastal bay that has measurable freshwater land drainage is considered an estuary; a river is not required. Of the four geomorphologic classes of estuaries (Duxbury, 1977; Saegar, 2012), three do not necessarily occur at river mouths. Bar-built estuaries are semi-confined by offshore islands or sandbars. 
They usually have low surface freshwater flow and high SGD flow, such as Pamlico and Albemarle Sounds along the North Carolina, United States, coast and Port Royal Sound on the South Carolina, United States, coast (Crotwell and Moore, 2003). Fjords are associated with coastlines where glaciers scoured deep valleys during low sea level stands. Continued glacial melt on the surrounding countryside and in some cases river input dilutes the fjord salinity. Fjords abound on the Greenland and Scandinavia coasts. Tectonic estuaries such as San Francisco Bay may or may not be associated with a river mouth. With the increased recognition of SGD, Conley et al. (2000) proposed redefining an estuary as "a partially enclosed body of water open to saline water from the sea and receiving freshwater from rivers, land run-off or seepage." On Hawaii there are few significant rivers, but there are many estuaries including harbors, coves and fishponds that derive freshwater from SGD (Johnson et al., 2008; Adolf et al., 2019). Equating surface estuaries with river mouths is incorrect. By extension a subterranean estuary need not be located only at a river mouth.

In addition to "transition zone" Jiao and Post (2019) suggested that the term "mixing zone" or "coastal aquifer" would be adequate to describe the system. Duque et al. (2020) proposed changing the term "subterranean estuary" to "subterranean mixing and reaction field." We do not advocate these changes. The significant problem in abandoning the term "subterranean estuary" would be to lose the connection to the rich estuarine literature that has described physical, chemical and biological processes that occur in this distinctive geological environment. In elementary oceanography texts (e.g., Duxbury, 1977; Saegar, 2012) students learn that estuaries are classified by morphology and by circulation. The circulation is primarily an interplay between the freshwater flow and tidal energy. These forces control the residence time of water in most surface estuaries, a critical parameter that modulates their biogeochemistry. Framing the subterranean estuary in these terms immediately conveys the importance of circulation in a way that "coastal aquifer," "mixing zone," "transition zone," or "subterranean mixing and reaction field" do not. We agree with Rocha et al. (2021) who "strongly advocate for the inclusion of subterranean estuaries as essential components of coastal ecosystem function research, monitoring, policy and management."

Robinson et al. (2007) introduced a classification system for subterranean estuaries based on salinity stratification (stratified, partially stratified, or well-mixed), a system widely used in surface estuaries where freshwater flow $\left(\mathrm{Q}_{\mathrm{f}}\right)$ as a fraction of the tidal prism $\left(Q_{t}\right)$ largely determines stratification. Substituting fresh groundwater flow for surface freshwater flow, they found that when $Q_{\mathrm{f}} / Q_{\mathrm{t}}$ was $>1.0$ the subterranean estuary was stratified. When $Q_{\mathrm{f}} / Q_{\mathrm{t}}$ was between 0.1 and 1 the subterranean estuary was partially stratified and when $Q_{\mathrm{f}} / Q_{\mathrm{t}}$ was $<0.1$, the subterranean estuary was well mixed. They pointed out that Schultz and Simmons (1957) found similar ranges of $Q_{f} / Q_{t}$ determined stratification in coastal plain surface estuaries.

In addition to salinity there are other transition zones within the subterranean estuary. One is between oxic and anoxic regions where sulfate becomes the primary electron acceptor, i.e., $\mathrm{SO}_{4}{ }^{2-}-\mathrm{S}^{2-}$. Within this region are suboxic transition zones: $\mathrm{NO}_{3}{ }^{-}-\mathrm{NO}_{2}{ }^{-}-\mathrm{NH}_{4}{ }^{+}, \mathrm{Mn}^{4+}-\mathrm{Mn}^{3+}-\mathrm{Mn}^{2+}, \mathrm{Fe}^{3+}-\mathrm{Fe}^{2+}$ Charette and Sholkovitz (2002) described the $\mathrm{Fe}^{3+}-\mathrm{Fe}^{2+}$ transition as the "iron curtain" transition zone in subterranean estuaries where soluble $\mathrm{Fe}^{2+}$ is oxidized to $\mathrm{Fe}^{3+}$ and precipitates, adsorbing important components such as phosphate. After sulfate is consumed there is a transition to methanogenesis. Each of these transition zones is populated by specific organisms, which mediate the measured reactions.

These transition zones within the subterranean estuary migrate in response to changes in circulation patterns (Charette and Sholkovitz, 2002). This migration stimulates different species of bacteria and archaea, which catalyze the biogeochemical reactions. For example, in studies of an intertidal aquifer, McAllister et al. (2015) found that the availability of chemical species controlled microbial populations along groundwater flow paths. They demonstrated that seasonal changes in the relative supply of fresh and saline groundwater affect microbial populations and noted that every pore water sample had a significant portion of sulfate reducers, making this the predominant recognized metabolism within the intertidal mixing zone. Degenhardt et al. (2020) described a "core community" of microbes in the upper meter of a high-energy intertidal area where stable redox transitions were driven by porewater advection and sediment reworking. This equilibrium community was disturbed by a "subsurface spring bloom," probably due to deeper penetration of oxygen and nitrate, but reverted to the "core community" during summer. Such dynamics illustrate the rapidity with which generalist microorganisms can respond to changing conditions within these transition zones.

In 2012 leaders in studies of anchialine environments decided to redefine the definition of their field of study. The title of the paper was “'Anchialine' redefined as a subterranean estuary in a crevicular or cavernous geological setting" (Bishop et al., 2015). This study and the ones by Charette and Sholkovitz (2002) and Robinson et al. (2007) are but three examples of the evolving rich literature on subterranean estuaries. As Moore (2010) pointed out, many surface estuarine processes have an analog in the subterranean estuary. Elucidating some of these processes is the purpose of this paper.

\section{Expansion of the Subterranean Estuary}

As saltwater intrusion brings more seawater into coastal aquifers, the subterranean estuary expands inland, significantly altering biogeochemical dynamics over wide regions. For example, in the early 1900's, a 100-500 m wide zone of brackish water lay at the base of the Biscayne aquifer in southern Florida (Barlow and Reichard, 2010). By 1946, canals constructed to drain the coastal wetlands above the unconfined aquifer resulted in the movement of brackish water 2 to $16 \mathrm{~km}$ inland, primarily beneath the canals, increasing the size of the subterranean estuary along this $25 \mathrm{~km}$ coastline from $\sim 20$ to over $120 \mathrm{~km}^{2}$ (Barlow and Reichard, 2010). This example has been repeated along coastlines worldwide.

Depletion of fresh groundwater through active pumping has accelerated during the past 50 years. For example, prior to 1950 , there was less than $1 \mathrm{~km}^{3}$ year ${ }^{-1}$ of groundwater depletion from the United States Gulf and Atlantic coastal plain 
aquifers; by 2008 this rate had increased to almost $9 \mathrm{~km}^{3}$ year $^{-1}$ (Figure 1; Konikow, 2011). Industrial use of groundwater places major demands on coastal aquifers, as evidenced by the changes occurring along coastal Georgia, United States, in the past $\sim 60$ years. Prior to October 1962, the Upper Floridan aquifer below the city of Brunswick, GA, had a hydraulic head of +3 to $+5 \mathrm{~m}$. In 1963, a paper mill began pumping roughly $1.4 \times 10^{5} \mathrm{~m}^{3}$ freshwater day ${ }^{-1}$ from the aquifer and within 14 months the head in the aquifer had dropped to $-3 \mathrm{~m}$ (Wait and Gregg, 1973). Within 30 years, a $5 \mathrm{~km}^{2}$ subterranean estuary developed beneath the city, rendering the city wells non-potable due to $1-2.5 \mathrm{~g} / \mathrm{L}$ chloride concentrations (Joiner, 1991). In China, saltwater intrusion along the coastline of the Laizhou Gulf in Shandong Province covered a total area of $16 \mathrm{~km}^{2}$ in 1979; 10 years later the area of saltwater intrusion was $238 \mathrm{~km}^{2}(\mathrm{Xu}$ et al., 2002). By 2000, the extent of saltwater in the aquifer reached $1870 \mathrm{~km}^{2}$, causing over 1500 wells to be abandoned (Qi and Qui, 2011). During the past century such examples have been repeated with similar consequenes along most populated coastlines (Werner et al., 2013).

The thawing of marine permafrost has the potential to produce new subterranean estuaries in the Arctic as ice is replaced with water. For example, Shakhova et al. (2010) suggested that the East Siberian Arctic Shelf (ESAS), an area of $2.1 \times 10^{6} \mathrm{~km}^{2}$ on the Arctic Ocean margin, is potentially more vulnerable to thawing than is terrestrial permafrost. The annual average temperature of ESAS bottom seawater ranges from -1.8 to $+1^{\circ} \mathrm{C}$; this is $12-17^{\circ} \mathrm{C}$ warmer than the annual average surface temperature over terrestrial permafrost. On the South Kara Sea shelf in the Arctic, Portnov et al. (2013) found continuous subsea-bed permafrost extending to water depths of $\sim 20 \mathrm{~m}$ offshore. The permafrost created a seal through which gas could not migrate. Further offshore they found discontinuous permafrost up to $115 \mathrm{~m}$ water depth where methane ebullition was occurring. They concluded that within this $7500 \mathrm{~km}^{2}$ area, seafloor gas release is widespread and permafrost degradation is an ongoing process. These are just examples of the thawing processes that are taking place around the Arctic Ocean margin. As ice is replaced with water in these permeable sediments, we posit that water exchange will take place between the sediments and the ocean, bringing these carbon-laden sediments into contact with seawater in new subterranean estuaries. This will substantially alter the biogeochemical dynamics of these systems, almost assuredly increasing the fluxes of carbon, nutrients, metals, and trace gases to the coupled ocean waters.

There is no doubt that the subterranean estuary is expanding rapidly as freshwater and ice are replaced by saltwater. The biogeochemical consequences of this expansion are significant globally.

\section{Biogeochemical Reactions in Coastal Aquifers}

Adding saltwater to a coastal aquifer changes the chemical environment dramatically. The increased ionic strength causes some particle-associated, surface-active ions to be released to solution. This increases the dissolved concentrations of desorbable ions such as ammonium, phosphate, barium, and radium (Moore, 1996; Shaw et al., 1998; Price et al., 2006). Another major change is reflected in the increased oxidation capacity of the saltwater. In terms of free energy, oxygen is the most powerful oxidant in natural waters. However, its oxidizing capacity is limited by its poor solubility $(\sim 0.28 \mathrm{mmol} / \mathrm{L}$ in freshwater). The reaction

$$
\mathrm{CH}_{2} \mathrm{O}+\mathrm{O}_{2} \rightarrow \mathrm{CO}_{2}+\mathrm{H}_{2} \mathrm{O}
$$

will cease when $0.28 \mathrm{mmoles} / \mathrm{L}$ of organic carbon have been oxidized in a closed system. If this carbon has a typical marine $\mathrm{C}: \mathrm{N}$ ratio $=6.6$, a maximum of $42 \mu \mathrm{mol} / \mathrm{L}$ dissolved inorganic $\mathrm{N}$ (DIN) would be regenerated. This places a constraint on the maximum DIN concentration in unpolluted, oxic freshwater aquifers. But once dissolved oxygen is depleted in saltwater, the sulfate ion $(\sim 28 \mathrm{mmol} / \mathrm{L}$ in seawater) becomes the primary electron acceptor for organic carbon oxidation. For example

$$
2 \mathrm{CH}_{2} \mathrm{O}+\mathrm{H}^{+}+\mathrm{SO}_{4}^{2-} \rightarrow 2 \mathrm{CO}_{2}+\mathrm{HS}^{-}+2 \mathrm{H}_{2} \mathrm{O}
$$

For each mole of sulfate reduced, 2 moles of organic carbon are oxidized and 2 moles of $\mathrm{CO}_{2}$ are produced. If enough labile organic matter is present to deplete sulfate completely by oxidizing $56 \mathrm{mmol}$ carbon with $\mathrm{C}: \mathrm{N}=6.6$, this reaction could potentially release $8.5 \mathrm{mmol} \mathrm{DIN} / \mathrm{L}$ in unpolluted aquifers containing marine organic carbon. Terrestrial organic matter contains a lower $\mathrm{C}: \mathrm{N}$ ratio; its oxidation would produce a lower concentration of DIN. The presence of sulfate minerals could provide additional sulfate ions and increase the DIN released from subterranean estuaries or from freshwater aquifers after oxygen is depleted (Chapelle and McMahon, 1991).

Early studies of sulfate reduction coupled to oxidation of marine organic matter (Martens et al., 1978) found that pore waters of anoxic marine sediments contained up to about $10 \mathrm{mmol}$ ammonia per liter. Riedel et al. (2011) reported $\mathrm{NH}_{4}$ concentrations of 7 to $9 \mathrm{mmol} / \mathrm{L}$ in pore waters from tidal flat sands in the German Wadden Sea in which the sulfate concentration had been reduced to $\sim 0$ and there was no source of DIN pollution. Wang and Jiao (2012) measured $\mathrm{NH}_{4}$ concentrations of 10-20 mmol/L in a non-polluted Quaternary salty aquifer in the Pearl River delta, China, in which all sulfate had been reduced.

Figure 2 illustrates some differences between freshwater oxic coastal aquifers (Figure 2A) and anoxic subterranean estuaries (Figure 2B), where sulfate becomes the primary oxidizing agent after oxygen is exhausted. Because of its high sulfate concentration, saltwater has a far greater oxidizing capacity than freshwater. The reaction products of sulfate reduction coupled to organic matter oxidation include both inorganic and organic forms of dissolved $\mathrm{C}, \mathrm{N}$, and $\mathrm{P}$ as well as hydrogen sulfide. The creation of sulfidic conditions in an aquifer stimulates reduction of iron and manganese oxides, which increases concentrations of $\mathrm{Fe}^{2+}$ and $\mathrm{Mn}^{2+}$, as well other metals and non-metals bound to these oxides. Increases of $\mathrm{PO}_{4}, \mathrm{Ba}, \mathrm{Ra}, \mathrm{Hg}, \mathrm{Mo}, \mathrm{V}$, rare earth elements (REE), and As are expected. As this chemically altered saltwater is discharged into coastal waters as SGD, it carries a high 


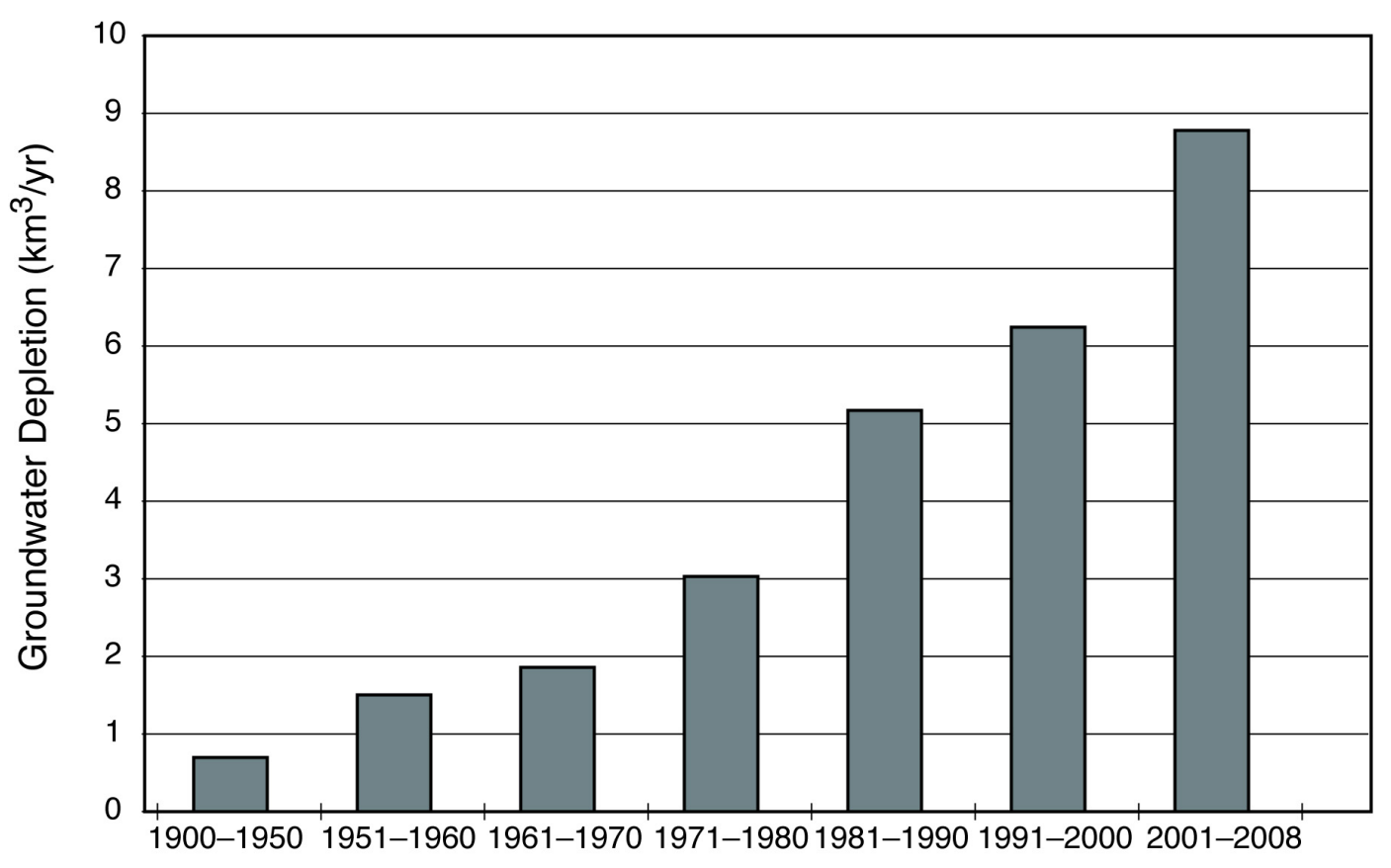

\section{Year}

FIGURE 1 | The depletion of groundwater in the United States Gulf and Atlantic Coastal plain aquifers. Before 1950 depletion rates were less than 1 km $/$ year. Early in the 21 st century this increased to almost $9 \mathrm{~km}^{3} / \mathrm{yr}$. Data from Konikow (2011).

load of nutrients, carbon, metals, and sulfides. While nutrient, carbon and metal concentrations in SGD may be augmented by anthropogenic contamination, even pristine systems may have highly elevated concentrations due to the stimulation of anaerobic microbial metabolisms.

Once oxygen is consumed, a biogeochemical cascade ensues, with nitrate reducing, iron and manganese reducing, sulfate reducing, and methanogenic microorganisms. Thermodynamic energy yield and kinetic constraints interact to dictate the net pattern metabolism: typically, nitrate reduction and metal oxide reduction occur before sulfate reduction which occurs before methanogenesis. Sulfate is typically present in higher concentration than the other electron acceptors, leading to the domination of sulfate reduction in anaerobic metabolism in these systems. However, biologically mediated reactions occur in tandem with abiotic reactions, making it difficult in some cases to assess the driving force behind the observed biogeochemical reactions (Joye and Kostka, 2020).

There are a number of ways to assess the importance of abiotic versus microbially mediated processes in aquifers. Assessing microbial community composition using genomics data (Joye and Kostka, 2020) provides information on genomic capacity for a particular reaction by tracking gene abundance (e.g., probing for genes or assessing metagenomes) or by tracking the presence of transcripts associated with a particular process (e.g., metatranscriptomics). While some studies utilized such techniques in coastal aquifers (Santoro et al., 2006, 2008; Rogers and Casciotti, 2010; Sáenz et al., 2012; Adyasari et al., 2019,
2020), this approach holds tremendous potential. Adyasari et al. (2019) found that temperature and salinity were the main factors driving microbial community composition in shallow aquifers. Adyasari et al. (2020) studied the microbial community in an aquifer near Mobile Bay, AL., which becomes hypoxic during the dry season due to discharge of $\mathrm{NH}_{4}{ }^{+}$-rich groundwater. They observed a robust community of organisms associated with dissimilatory nitrate reduction to ammonia in the aquifer and proposed that these organisms may contribute to $\mathrm{NH}_{4}{ }^{+}$-loading in the estuary.

Rogers and Casciotti (2010) found a unique population of ammonia oxidizing archaea in well ventilated sediments in a coastal aquifer on Cape Cod and suggest a role for these organisms in nitrification. Sáenz et al. (2012) studied the anaerobic oxidation of ammonium (anammox) in a subterranean estuary in Waquoit Bay MA. They found anammox bacteria were present in redox transition zones where ammonium and nitrate coexist. Santoro et al. (2006) examined the population of denitrifying bacteria in a beach aquifer near Huntington Beach, CA, and were able to resolve population shifts over small spatial scales. They suggest that subtle differences in aquifer chemistry can result in microbial community shifts. In a subsequent paper (Santoro et al., 2008) they compared the abundance of ammonia oxidizing bacteria with that of ammonia oxidizing archaea, revealing that the ammonia oxidizing archaea preferred lower salinities (brackish and freshwater) than the ammonia oxidizing bacteria. 


\section{A}
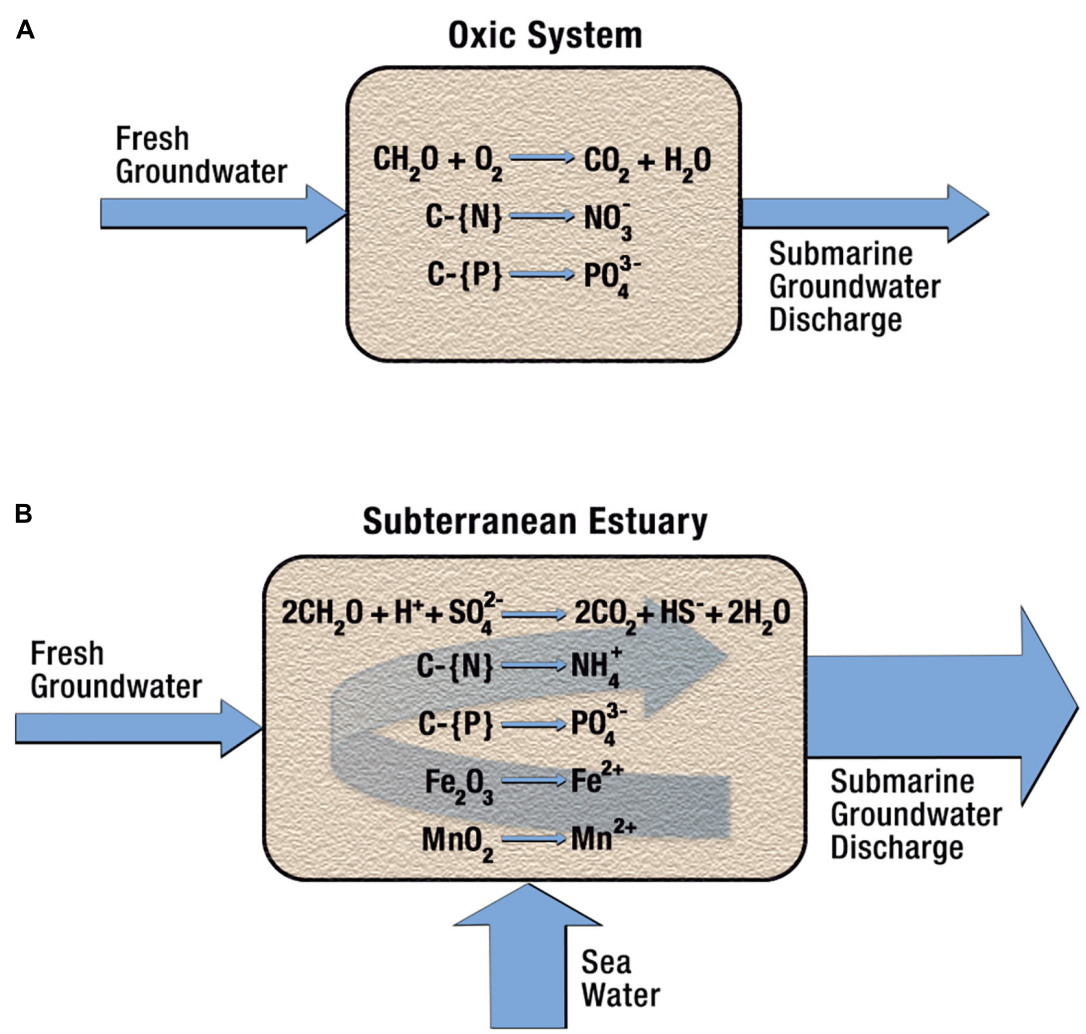

FIGURE 2 | Chemical differences between an oxic freshwater aquifer and an anoxic subterranean estuary. (A) As fresh oxygenated groundwater passes through an aquifer containing organic carbon, some carbon may be oxidized and release $\mathrm{CO}_{2}$ as well as nitrate and phosphate ions. The maximum concentration of nitrate produced $(\sim 42 \mu \mathrm{M})$ is controlled by the solubility of oxygen ( $0.28 \mathrm{mM})$ and the $\mathrm{C}: \mathrm{N}$ ratio of the organic matter ( 6.6 for marine organic matter). (B) The addition of saltwater to this system greatly increases the oxidizing capacity after $\mathrm{O}_{2}$ is exhausted due to sulfate ion ( $28 \mathrm{mM}$ in ocean water). Here the reaction products include significantly greater concentrations of $\mathrm{CO}_{2}$, ammonium and phosphate as well as sulfide, which can reduce metal oxides, liberating Fe ${ }^{2+}$ and $\mathrm{Mn}^{2+}$ and other metals and non-metals to solution.

While genomics methods provide information about metabolic potential and about active gene expression, another way to assess microbial activity directly involves using metabolic inhibitors in combination with radiotracer rate assays. Metabolic inhibitors specifically block enzymes associated with a particular process and hence can be used to separate microbial activity from abiotic processes (Segarra et al., 2013), but again such approaches are rarely applied to aquifer systems. Pairing genomics and targeted rate assays with standard geochemical approaches offers a robust way to advance a number of research areas related to SGD in the coastal zone. Much of the work to date has focused on nitrogen cycling but there is tremendous potential for advancing the understanding in carbon and sulfur cycling using these approaches as well.

\section{RESULTS: CASE STUDIES}

To illustrate the processes we have just described on different spatial and temporal scales, as posited by Bratton (2010), we offer three case studies of radically different environments: a small river-salt marsh system in South Carolina, offshore tidal flats in the German Wadden Sea, and a section of the
Potomac Subterranean Estuary, a 45,000 km² system beneath the United States east coast. Here we reinterpret published data from each system.

\section{Okatee, South Carolina (United States)}

The Okatee subterranean estuary lies in southeastern South Carolina, northwest of Hilton Head Island. Previous studies revealed large SGD fluxes of nutrients and carbon (Moore et al., 2006; Weston et al., 2006b; Porubsky et al., 2014). These studies used data collected when the area had a low population density before a large-scale housing development was built in the upper reaches of the system. Monitoring wells along the creek bank were sampled for numerous constituents including dissolved nutrients, carbon, chloride, sulfate, and radium (Moore et al., 2006). The salinity of these well waters ranged from $\sim 25$ to $>40$, the higher values arising from evapotranspiration. Figure 3 shows the relationship between some of these constituents and the degree of sulfate depletion, via microbial sulfate reduction, observed in groundwater from the monitoring wells. Sulfate depletion is defined as the sulfate concentration observed in the groundwater minus the sulfate concentration predicted from the $\mathrm{Cl}^{-}$concentration. Here we assume seawater entered the aquifer 
with the oceanic $\mathrm{SO}_{4}: \mathrm{Cl}$ molar ratio (0.0514) and is the only source of $\mathrm{SO}_{4}$. Following Martens et al. (1978), who developed this concept in anoxic mud, we call the depletion of $\mathrm{SO}_{4}$ " $\Delta \mathrm{SO}_{4}$ "; this term becomes more negative with increased sulfate depletion.

As predicted by reaction (2), the concentration of dissolved $\mathrm{CO}_{2}$ increases with a 2:1 ratio as sulfate is depleted. The concentration of dissolved $\mathrm{NH}_{4}{ }^{+}$reaches $400 \mu \mathrm{M}$ in samples showing the greatest (about 50\%) sulfate depletion. This is an order of magnitude greater than the concentration expected from the oxidation of marine organic matter by dissolved oxygen, illustrating the dramatic effect that saltwater intrusion has on the biogeochemistry of coastal aquifers. The scatter is likely caused by differences in the $\mathrm{C}: \mathrm{N}$ ratio of the material being oxidized [literature values for Spartina, the primary marsh grass in this system, show C:N of 14-74 (Porubsky et al., 2014)]; the soils may also contain terrestrial plant components with even higher C:N ratios and $\mathrm{NH}_{4}{ }^{+}$may exhibit non-conservative behavior after it is released. Dissolved ${ }^{226} \mathrm{Ra}$ (half-life $=1600$ years) also increases strongly with increased sulfate depletion. Because ${ }^{226} \mathrm{Ra}$ regenerates very slowly after being desorbed from particles, the increased ${ }^{226} \mathrm{Ra}$ activity in the sulfate-depleted water must be due to its release from the diagenesis of solids in the aquifer. Whether this is due to oxidation of organic matter directly or to subsequent reactions involving Fe-Mn coatings or other components is unknown. Porubsky et al. (2014) demonstrated strong correlations between ${ }^{226} \mathrm{Ra}$ and dissolved DIN, DIP, DIC, and DOC in these wells, reinforcing the idea of stoichiometry in the release of ${ }^{226} \mathrm{Ra}$ during organic matter oxidation. Unlike ${ }^{226} \mathrm{Ra}$, dissolved ${ }^{228} \mathrm{Ra}$ (half-life $=5.7$ years) shows an irregular pattern with high activities occurring at high and low sulfate depletion. This must be due to the continued regeneration of ${ }^{228} \mathrm{Ra}$ from ${ }^{232} \mathrm{Th}$ decay on particles within the flow-path of the groundwater $\left(\sim 30 \%\right.$ of ${ }^{228} \mathrm{Ra}$ regenerates in 1 year from ${ }^{232} \mathrm{Th}$ decay). On a timescale of months to years, the high ionic strength of the water desorbs regenerated ${ }^{228} \mathrm{Ra}$ irrespective of the sulfate depletion. These high ${ }^{226} \mathrm{Ra}$ and ${ }^{228} \mathrm{Ra}$ activities provide effective tracers of SGD that enters estuarine and coastal waters.

\section{Wadden Sea Tidal Flats, Germany}

Within the Wadden Sea in northern Germany, some tidal flats are exposed only during low tide. Numerous studies of pore waters within the sandy tidal flats near Spiekeroog Island have documented high concentrations of $\mathrm{NH}_{4}, \mathrm{PO}_{4}$, DIC, DOC, $\mathrm{Mn}$, $\mathrm{Fe}, \mathrm{Ba}$, and $\mathrm{Ra}$ and the release of these components to tidal waters during low tide (Billerbeck et al., 2006; Beck et al., 2008a,b; Moore et al., 2011). Here we focus on a study by Riedel et al. (2011) who mapped the interstitial water chemistry down to $2.5 \mathrm{~m}$ sediment depth along a transect on an inter-tidal creek bank that is subject to a periodic advective flow. They documented high rates of diagenetic reactions in sites subject to advection compared to sites controlled by diffusion. On a timescale of 200 days, $\mathrm{SO}_{4}$ was almost completely depleted, while DIC, $\mathrm{NH}_{4}, \mathrm{Ba}, \mathrm{Mn}$, and $\mathrm{V}$ became highly elevated (Riedel et al., 2011). When plotted against $\Delta \mathrm{SO}_{4}$ (Figure 4), these increases follow the same trends observed in the Okatee dataset (Figure 3). Again, the DIC increases with a 2:1 ratio as $\mathrm{SO}_{4}$ is depleted. The $\mathrm{NH}_{4}$ concentration reaches $8.5 \mathrm{mmol} / \mathrm{L}$, the predicted concentration based on the Redfield
Ratio for marine organic material of $\mathrm{C}: \mathrm{N}=6.6$. Ba shows irregular but significant increases, while the $\mathrm{V}$ increase is very linear. All of these concentrations are orders of magnitude greater than North Sea water (Moore et al., 2011) and further underscore the role of anaerobic microbial metabolisms in enriching groundwater with reduced metabolites.

\section{The Potomac Subterranean Estuary Offshore New Jersey, United States}

The Potomac aquifer lies within the Northern Atlantic Coastal Plain aquifer system, which comprises much of the subterranean coastal area from North Carolina to New Jersey. The aquifer extends under the land and beneath the continental shelf. There has been significant saltwater intrusion into this aquifer in response to multiple sea level cycles (Barlow, 2003). This has created an enormous $\left(\sim 45,000 \mathrm{~km}^{2}\right)$ subterranean estuary. The IODP Expedition 313 collected a series of deep cores into this system along an inshore to offshore transect off the coast of New Jersey (Mountain et al., 2010). The chemistry of the pore water extracted from these cores was presented by van Geldern et al. (2013). The pore water had salinities as low as $1-2$ in some fine-grained silty and clay-rich sediments. The $\delta^{18} \mathrm{O}$ and $\delta^{2} \mathrm{H}$ values of the water were similar to modern precipitation, indicating recharge by meteoric water via onshore outcrops at times of high sea level. The authors could not determine if this freshwater recharge occurred in modern times or at a time when conditions were similar to the present, i.e., the last interglacial, 120,000 years ago; they concluded recharge did not occur during low glacial sea level as some had suggested.

The more permeable sediments contained saltier water, ranging from brackish to hypersaline. The highest salinity samples probably represent upward migration of a deep brine (van Geldern et al., 2013). Based on stable isotope data, van Geldern et al. (2013) concluded that the porewaters in the upper layers with salinity less than 35 resulted from mixing of meteoric waters with seawater; in deeper layers where salinity was greater than 35 , the deep brine was a significant component. Overall, the geochemical results for major ions and stable isotopes in the lower salinity porewaters were in good agreement with modern meteoric and seawater values, indicating possible connections to the seafloor through channels in less permeable layers or through outcrops at the shelf margin (van Geldern et al., 2013). However, not all of the chemical parameters could be described by simple mixing, as the porewaters were high in alkalinity, ammonium, and phosphate and depleted in sulfate. These observations fit the concept of the diagenetic reactions in the subterranean estuary very well.

Here we use the pore water data for Expedition 313 reported on the IODP website (Integrated Ocean Drilling Program [IODP], 2020). To avoid the effect of the deep brine component, we restrict our attention to samples from the upper 340$450 \mathrm{~m}$ sections, which van Geldern et al. (2013) interpret as primarily mixing between meteoric recharge and seawater. These samples contained less than seawater concentrations of $550 \mu \mathrm{M}$ chloride. As in the other systems, we observe significant increases in $\mathrm{NH}_{4}$ as $\Delta \mathrm{SO}_{4}$ decreases (Figure 4). The $\mathrm{NH}_{4}$ 

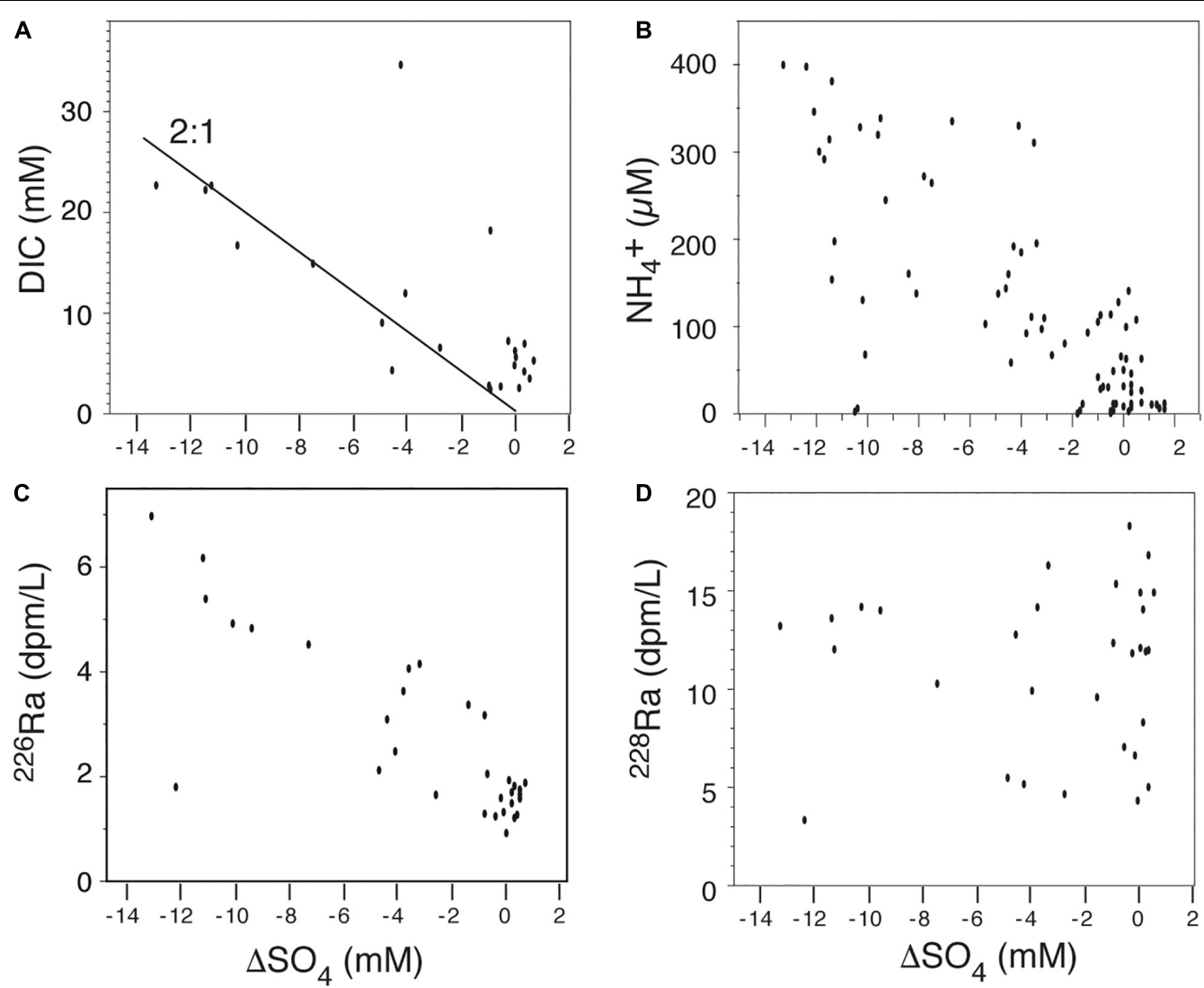

FIGURE 3 | Data from the Okatee subterranean estuary, South Carolina, showing the relationship between sulfate depletion by $\mathrm{C}$ oxidation (see text) and dissolved species. (A) The concentration of dissolved $\mathrm{CO}_{2}$ increases with a 2:1 ratio as sulfate is depleted (Eq. 2). (B) The concentration of dissolved $\mathrm{NH}_{4}{ }^{+}$reaches $400 \mu \mathrm{M}$ in samples with the greatest sulfate depletion. (C) Dissolved ${ }^{226}$ Ra increases with increased sulfate depletion, implying organic matter degradation either directly or due to secondary reactions releases significant ${ }^{226} \mathrm{Ra}$. (D) Dissolved ${ }^{228}$ Ra shows an irregular pattern with high activities occurring at high and low sulfate depletion, implying that desorption of ${ }^{228} \mathrm{Ra}$ regenerated from ${ }^{232}$ Th decay governs its behavior. Data from Moore et al. (2006) and Porubsky et al. (2014).

increase is intermediate between systems containing primarily marine organic matter like the Wadden Sea and systems where the material being oxidized has a higher $\mathrm{C}: \mathrm{N}$ ratio. If the increased $\mathrm{NH}_{4}$ is due to its release from organic matter, its $\mathrm{C}: \mathrm{N}$ ratio is probably between 6 and 23, based on the slope of the $\Delta \mathrm{SO}_{4}$ curve. This seems reasonable for the oxidation of a mixture of terrestrial (high $\mathrm{C}: \mathrm{N}$ ) and marine (low $\mathrm{C}: \mathrm{N}$ ) organic matter. Obviously, there are other processes at work in these porewaters. For example, the very high $\mathrm{NH}_{4}$ and $\mathrm{Ba}$ values in cases where there is no sulfate deficiency (Figure 5) may be due to desorption from the solid phase rather than re-mineralization. It could also be due to the addition of new sulfate from the dissolution of sulfate minerals such as gypsum in the sediments.

\section{DISCUSSION}

\section{Earlier Studies}

There have been earlier studies linking seawater intrusion with biogeochemical reactions in the subterranean estuary; we will cite a few. Sivan et al. (2005) investigated chemical changes in seawater intrusions along the Mediterranean coast of Israel. They used nuclear bomb-derived ${ }^{3} \mathrm{H}$ to verify that the intruding water 50-100 $\mathrm{m}$ onshore had been in the ocean 15-30 years ago. These samples contained total alkalinity and total dissolved inorganic carbon (DIC) in excess of that predicted from aerobic metabolism, indicating anaerobic oxidation of organic matter. In the Florida Everglades, Price et al. (2006) proposed that phosphorus discharge to the surface water was influenced by saltwater intrusion. In the Indian River Lagoon, Florida, Roy et al. (2010) studied the effect of sea level rise on the Fe flux to ocean surface waters through SGD. Fifteen $\mathrm{km}$ seaward of the North Carolina coast, Moore et al. (2002) found high nutrient concentrations in 2-4 m deep seabed monitoring wells; both total dissolved $\mathrm{N}$ and $\mathrm{P}$ correlated strongly with ${ }^{226} \mathrm{Ra}$, as they did in the Okatee system.

It is clear that saltwater intrusion accelerates biogeochemical dynamics in subterranean estuaries, with potentially profound impacts on the geochemistry of SGD. Luo et al. (2018) reached the same conclusion in their study of the Pearl River aquifer, China, where they documented increased ${ }^{226} \mathrm{Ra}$ and $\mathrm{NH}_{4}$ with $\Delta \mathrm{SO}_{4}$ similar to our case studies. In their system, $\mathrm{NH}_{4}$ reached $22 \mathrm{mM}$, clearly exceeding the $8.5 \mathrm{mM}$ theoretical 

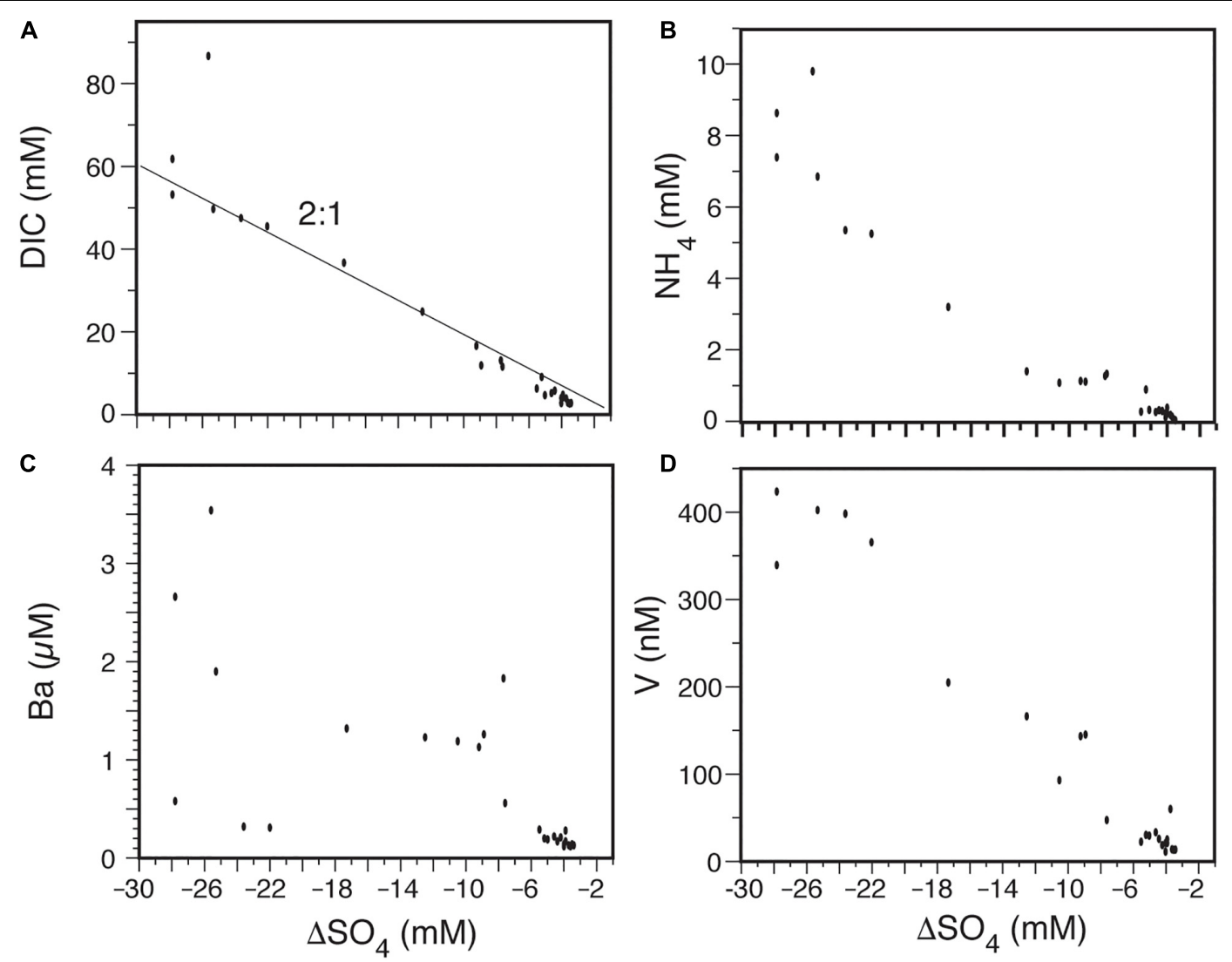

FIGURE 4 | Data from the Wadden Sea tidal flats, Germany, showing the relationship between sulfate depletion by C oxidation (see text) and dissolved species. (A) The concentration of dissolved $\mathrm{CO}_{2}$ increases with a 2:1 ratio as sulfate is depleted (Eq. 2). (B) The concentration of dissolved $\mathrm{NH}_{4}+$ reaches $8.5 \mathrm{mM}$ in samples with the greatest sulfate depletion as predicted using the Redfield Ratio. (C) Dissolved Ba increases irregularly with increased sulfate depletion, implying organic matter degradation releases significant Ba either directly or due to secondary reactions. (D) Dissolved vanadium shows a highly linear increase with sulfate depletion, implying organic matter degradation releases significant V. Data from Riedel et al. (2011).

value for the oxidation of marine organic carbon. Because there is no evidence for anthropogenic pollution on a large scale in this system (Wang and Jiao, 2012), Luo et al. (2018) postulated that the high concentrations were likely caused by excess $\mathrm{NH}_{4}$ in initial fresh groundwater through other remineralization processes-such as Fe-Mn oxide reduction and methanogenesis-before mixing with saltwater and experiencing sulfate reduction. These high concentrations could also reflect ammonia adsorption to the organic-rich sediments during initial stages of saltwater intrusion when the salinity of the water was low, followed by its release when salinity increased. Wang and Jiao (2012) reported the exchange of $\mathrm{Mg}^{2+}$ and $\mathrm{NH}_{4}{ }^{+}$ in the aquitard of the Pearl River delta, possibly reflecting this process. The presence of gypsum in the sediments could provide another source of sulfate unrelated to saltwater in this or other systems.

\section{Changing Subterranean Estuaries and SGD}

Local changes in water and land use have led to enormous expansions of subterranean estuaries in the last 100 years.
This expansion has brought high ionic strength seawater containing sulfate into contact with old sediments. Sudden exposure of aquifer sediments to high ionic strength water may mobilize surface-bound ions and organic matter adsorbed onto sediments and alter the mineralogy of metal oxides (Weston et al., 2006a). Both of these effects may further accelerate biogeochemical reactions in aquifers impacted by saltwater intrusion by mobilizing the components of organic matter and increasing the availability of iron and manganese oxides for microbial reduction.

In effect, the introduction of sulfate ion transforms these aquifers from oxidant-limited to almost oxidant-unlimited, allowing extensive amounts of organic carbon to be oxidized. These changes stimulate the biogeochemical reactions that degrade organic matter via anaerobic metabolisms, leading to increased concentrations of nutrients, dissolved carbon (DIC and DOC), hydrogen sulfide and metals in the subterranean estuary. Fluids expelled from subterranean estuaries as SGD enrich coastal waters in nutrients, carbon, sulfide, and metals. In some cases, the excess nutrients can be linked to harmful algae blooms, eutrophication and hypoxia. For example, SGD has been cited as the most likely source of excess nutrients 

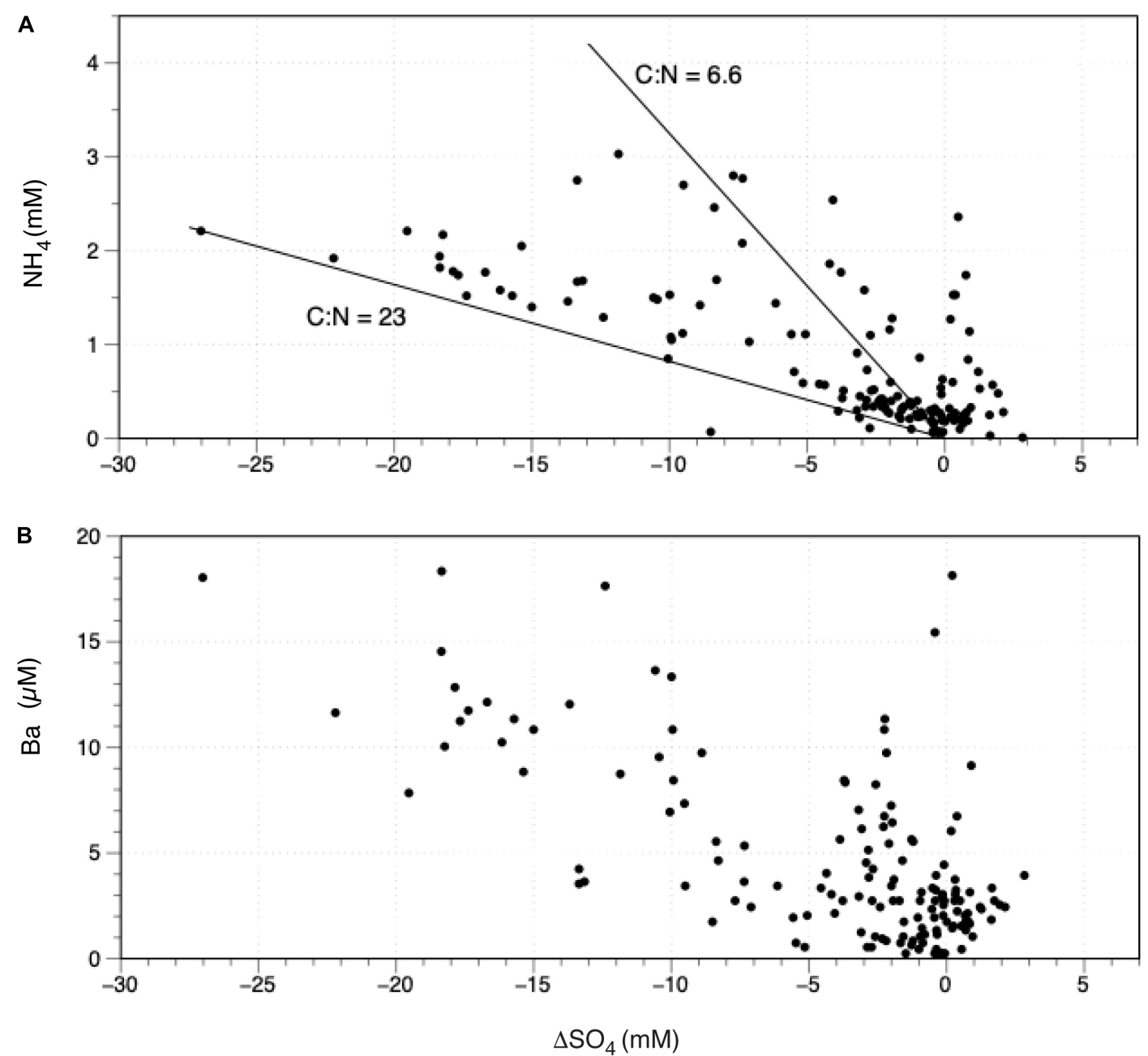

FIGURE 5 | Data from the IODP Exp 313, holes M0027A, M0028A, and M0029A on the continental shelf off New Jersey, showing the relationship between sulfate depletion by $\mathrm{C}$ oxidation (see text) and dissolved species in the upper levels of these cores. (A) The concentration of dissolved $\mathrm{NH}_{4}{ }^{+}$increases with sulfate depletion in a range between that predicted by oxidizing carbon with a 6.6 C:N ratio (Redfield Ratio) and a much higher ratio (23), implying the oxidation of non-marine carbon. (B) Dissolved Ba increases substantially with increased sulfate depletion, implying organic matter degradation releases significant Ba either directly or due to secondary reactions. High concentrations of $\mathrm{NH}_{4}$ and $\mathrm{Ba}$ also exist in multiple samples showing no sulfate depletion, indication that other processes such as desorption or the release of sulfate from solid phases also play a role. Data from van Geldern et al. (2013), Integrated Ocean Drilling Program [IODP] (2020).

in Yeoja Bay (Hwang et al., 2005) and Masan Bay (Lee et al., 2009), South Korea, where harmful algae blooms are common. $\mathrm{Hu}$ et al. (2006) observed that nutrient fluxes from local rivers were insufficient to support a harmful algae bloom in coastal waters off west Florida; they concluded that the most likely source of the required nutrients was high fluxes of SGD resulting from a hurricane.

Discharge of high-nutrient groundwater has also been implicated in eutrophication in Tolo Harbor, Hong Kong (Tse and Jiao, 2008). Recently Peterson et al. (2016) reported a nearhypoxic event on the South Carolina coast that was caused by the release of cold, salty, anoxic water from the offshore subterranean estuary. This discharged water formed a high-density benthic boundary layer that largely maintained its identity for several weeks as it spread to a nearshore monitoring station. Thus, SGD fluxes may have significant ecological impacts locally, and in some cases may have global impacts on ocean chemistry (Moore, 2010).

We want to be clear that the $\Delta \mathrm{SO}_{4}$ correlations that we present do not apply to all subterranean estuaries. We have examined data from systems where there are no correlations. The chemical signatures are not simple mixtures of groundwater and seawater but depend on the composition and reactivity of the aquifer and aquiclude solids, the residence time of fluids in the system, and the time that has elapsed since seawater first intruded the system. Understanding what regulates the chemical composition of fluids in subterranean estuaries is a complex and ongoing challenge.

Seawater intrusion into coastal aquifers will likely accelerate as coastal populations increase and sea levels continue to rise. Recent projections of multi-meter sea level rise over the next 50200 years (Hansen et al., 2016) will cause enormous additional inland expansion of subterranean estuaries. New subterranean 
estuaries will emerge in coastal aquifers and in the Arctic as ice is replaced with seawater. These processes will affect portions of aquifers that have not been in contact with saltwater for thousands of years, causing increased production of dissolved nutrients, carbon, sulfide, and metals, and possibly dissolved greenhouse gases, like methane, which accumulate in coastal aquifers (Schutte et al., 2016, 2020) and are trapped in permafrost (Shakhova et al., 2010). The increased biogeochemical reactions that affect these concentrations will operate over larger spatial scales, providing new sources of organic carbon for oxidation.

We must also consider what happens when aquifers that have accumulated saltwater are abandoned as water supplies. As Qi and Qui (2011) point out, seawater intrusion has caused over 1500 wells to be abandoned along the Laizhou Gulf coastline. If the natural flow of groundwater into these systems has not changed, they will recharge with freshwater and discharge the salty water containing the products of anaerobic metabolisms into estuaries or coastal waters. This would cause a release of nutrients, carbon, sulfide, and metals, and possible radiative trace gases like methane and nitrous oxide, to the adjacent coastal waters, potentially leading to or exacerbating eutrophication of the receiving waters over periods of years to decades. The rate of release will depend on the aquifer permeability and whether this has been affected by the saltwater-induced reactions. Jiao and Post (2019) cite examples of such flow reversal as wells are abandoned and point out that because of its higher density saltier water may collect in the deeper regions of the aquifer in spite of renewed recharge. Following the designations of Robinson et al. (2007), the renewed influx of freshwater may transform subterranean estuaries from well- or partially-mixed systems into stratified systems. Similar changes occur on a much shorter timescale in surface estuaries following a large discharge event.

These observations linking the recent expansion of subterranean estuaries with a mechanism for producing high concentrations of nutrients, carbon and metals in their fluids raises a significant question regarding SGD: Has the current supply of nutrients, carbon and metals to the ocean via SGD changed significantly in the past 100 years? We suggest that it may have increased even if the net freshwater flow may have decreased. Roy et al. (2010) concluded that accelerated sea level rise is likely to increase the Fe flux to ocean surface waters along coastlines where groundwater discharges through permeable sediments. This may be true for nutrients also. Because they lack high concentrations of sulfate ion, unpolluted freshwater springs are generally limited to a maximum of $42 \mu \mathrm{M}$ DIN. Compare this to orders of magnitude higher $\mathrm{N}$ concentrations in fluids in subterranean estuaries (up to $10 \mathrm{mM}$ ). Small increases in SGD from subterranean estuaries can more than compensate for diminished freshwater springs in terms of $\mathrm{N}$ delivery to the coast. Besides tides, other periodic changes in sea level constitute effective drivers of SGD. Seasonal sea level changes result from summertime heating, which expands the ocean and causes sea level to rise and intrude further into subterranean estuaries. During winter sea level falls causing a return flow of fluids that have become enriched in metabolic products. These seasonal changes are being amplified by climate change. Wahl et al. (2014) used seasonal sea level harmonics throughout the 20th and early 21st centuries to document a significant amplification of the annual sea level cycle in the eastern Gulf of Mexico of up to $30 \%$ (average 22\%) from the 1990s, brought on by both higher summer and lower winter sea levels. Shorter-term changes in sea level result from cyclones and other major storms (Moore and Wilson, 2005; Wilson et al., 2011) or persistent offshore wind events (George et al., 2020). There is growing evidence that cyclones are increasing in intensity and perhaps numbers. We speculate that persistent offshore wind events may also be linked to a warmer ocean. The combined effects of these sea level changes should drive increased exchange between the subterranean estuary and ocean, resulting in increased delivery of nutrients, carbon, and metals to the coastal ocean.

\section{Looking to the Future by Studying the Past}

Climate change is certainly affecting SGD forcing functions. Although we cannot determine how this will be affecting SGD globally at present, a future answer may be provided by proxy records in corals. These records offer promise in the future to address this question.

Horta-Puga and Carriquiry (2012) measured Ba/Ca ratios in a 52 -year old coral colony in Yucatan, Mexico. They found strong correlations between annual precipitation and the $\mathrm{Ba} / \mathrm{Ca}$ coral time-series and concluded that $\mathrm{Ba} / \mathrm{Ca}$ ratios can be used as a proxy of precipitation, which in the Yucatan is a direct indicator of SGD as there is minimal surface runoff (Young et al., 2008). Jiang et al. (2018) measured variations of REE/Ba and REE/Ca ratios in coral samples from Hainan Island, China, and used these as a long-term ( $>100$ year) proxy for SGD in the study area. They observed an increase in the reconstructed SGD corresponding to the escalating trend of local rainfall and suggested that "coral paleohydrological records can contribute to model-data comparisons in SGD models under different pumping scenarios."

Chen et al. (2020) measured $\mathrm{Ba} / \mathrm{Ca}, \delta^{18} \mathrm{O}$, and $\delta^{13} \mathrm{C}$ in coral skeletal material from the nearshore reef environment in the Kimberley Region of Northwestern Australia. They concluded the skeletal material contained significant terrestrial signatures of $\mathrm{Ba} / \mathrm{Ca}$, residual $\delta^{18} \mathrm{O}$, and to a lesser extent $\delta^{13} \mathrm{C}$ on a monthly time scale. These signatures as well as the observational coastal sea surface salinity exhibited a consistent lag with respect to river discharge of 1-2 months. They listed groundwater input as a possible cause for this lag but could not verify this possibility. Michael et al. (2005) observed that SGD often lags high precipitation events by several months. It is conceivable that the coral signatures were tracing SGD rather than river discharge.

Erler et al. (2018) analyzed coral skeletons from a reef core dating over 100 years in Rarotonga, Cook Islands, in the South Pacific for tracers of agriculture-related groundwater nitrogen, which is enriched in $\delta^{15} \mathrm{~N}$. They related increases in the $\delta^{15} \mathrm{~N}$ of coral skeletal material between 1960 and 2000 to rapid agricultural development that occurred between 1960 and 1985, which increased aquifer $\mathrm{N}$ concentrations leading to the elevated $\delta^{15} \mathrm{~N}$ of groundwater $\mathrm{NO}_{3}$. They realized the discharge of this $\mathrm{N}$-enriched groundwater continued for at least 15 years after the end of the agricultural boom, highlighting the important 
implications for the management of groundwater contamination. Erler et al. (2020) extended these studies to a 333-year composite record of $\delta^{15} \mathrm{~N}$ in coral skeleton-bound organic matter to understand how nitrogen cycling in the coastal Great Barrier Reef, Australia, has responded to increased anthropogenic nutrient inputs. They concluded that increased nitrogen fixation was the primary cause of increases $\mathrm{N}$ supply to the region.

We encourage similar studies to reconstruct the history of SGD along other coastlines and specifically to evaluate its effect on the receiving waters. Although the measurement of ${ }^{226} \mathrm{Ra}$ in small samples is time-consuming (Hsieh and Henderson, 2011; Yaala et al., 2019), the ${ }^{226} \mathrm{Ra} / \mathrm{Ca}$ ratios in corals may provide a direct link to the numerous studies of SGD using radium isotopes (Charette et al., 2008; Tan et al., 2018; Tamborski et al., 2020).

\section{CONCLUSION}

Reactions between fluids and solids in coastal aquifers are amplified dramatically upon the intrusion of seawater. This intrusion causes desorption of adsorbed ions and the oxidation of organic carbon via sulfate reduction in subterranean estuaries. These fluids become enriched in dissolved nutrients, inorganic carbon, organic carbon, sulfide, metals, radiative gases and radionuclide tracers. Circulation of these fluids between the subterranean estuary and the coastal ocean enriches coastal waters in these reaction byproducts, where they may enhance biological productivity and lead to increased biomass. The increased biomass may have positive societal results if it leads to increased seafood production or negative consequences if it leads to eutrophication, harmful algae blooms, and hypoxia. In some cases, the discharge of anoxic groundwater may directly

\section{REFERENCES}

Adolf, J. E., Burns, J., Walker, J. K., and Gamiao, S. (2019). Near shore distributions of phytoplankton and bacteria in relation to submarine groundwater dischargefed fishponds, Kona coast, Hawai'i, USA. Estuar. Coast. Shelf Sci. 219, 341-353. doi: 10.1016/j.ecss.2019.01.021

Adyasari, D., Hassenrück, C., Oehler, T., Sabdaningsih, A., and Moosdorf, N. (2019). Microbial community structure associated with submarine groundwater discharge in northern Java (Indonesia). Sci.Total Environ. 689, 590-601. doi: 10.1016/j.scitotenv.2019.06.193

Adyasari, D., Hassenrück, G., Montiel, D., and Dimova, N. (2020). Microbial community composition across a coastal hydrological system affected by submarine groundwater discharge (SGD). PLoS One 29:e023523. doi: 10.1371/ journal.pone.0235235

Barlow, P. M. (2003). Groundwater in Freshwater-Saltwater Environments of the Atlantic Coast. Reston, VA: U.S. Dept. Interior, USGS.

Barlow, P. M., and Reichard, E. G. (2010). Saltwater intrusion in coastal regions of North America. Hydrogeol. J. 18, 247-260. doi: 10.1007/s10040-009-0514-3

Beck, M., Dellwig, O., Holstein, J. M., Grunwald, M., Liebezeit, G., Schnetger, B., et al. (2008a). Sulphate, dissolved organic carbon, nutrients and terminal metabolic products in deep pore waters of an intertidal flat. Biogeochemistry 89, 221-238. doi: 10.1007/s10533-008-9215-6

Beck, M., Dellwig, O., Liebezeit, G., Schnetger, B., and Brumsack, H.-J. (2008b). Spatial and seasonal variations of sulphate, dissolved organic carbon, and nutrients in deep pore waters of intertidal flat sediments. Estuar. Coast. Shelf Sci. 79, 307-316. doi: 10.1016/j.ecss.2008.04.007 cause hypoxia (Peterson et al., 2016). We conclude that the well-documented accelerating intrusion of seawater into coastal aquifers will increase the concentrations of these reaction products and suggest that continued circulation between the subterranean estuary and coastal ocean will release increasing concentrations of these byproducts. We argue that the effects of climate change will increase this circulation due to shortterm and seasonal sea level changes. This circulation may also be temporarily enhanced if the rate of freshwater withdrawal from the aquifer diminishes and the normal flow of fresh groundwater into the aquifer continues, causing more SGD.

\section{AUTHOR CONTRIBUTIONS}

Both authors listed have made a substantial, direct and intellectual contribution to the work, and approved it for publication.

\section{FUNDING}

This work was funded by South Carolina (NA960PO113, the LU-CES program) and Georgia (NA06RG0029-R/WQ11 and R/WQ12A) Sea Grant and the National Science Foundation (EAR-1316250, OCE-1458424, and OCE-1736321).

\section{ACKNOWLEDGMENTS}

We thank Carolyn Ruppel, Nat Weston, Bill Porubsky, and Virginia Saunders for assistance with sample collections, analysis and figure preparation.

Billerbeck, M., Werner, U., Polerecky, L., Walpersdorf, E., de Beer, D., and Huettel, M. (2006). Surficial and deep pore water circulation governs spatial and temporal scales of nutrient recycling in intertidal sand flat sediment. Mar. Ecol. Progr. Ser. 326, 61-76. doi: 10.3354/meps326061

Bishop, R. E., Humphreys, W. F., Cukrov, N., Žic, V., Boxshall, G. A., Cukrov, M., et al. (2015). 'Anchialine' redefined as a subterranean estuary in a crevicular or cavernous geological setting. J. Crustacean Biol. 35, 511-514. doi: 10.1163/ 1937240X-00002335

Bratton, J. F. (2010). The Three Scales of Submarine Groundwater Flow and Discharge across Passive Continental Margins. J. Geol. 118, 565-575. doi: $10.1086 / 655114$

Burnett, W. C., Bokuniewicz, H., Huettel, M., Moore, W. S., and Taniguchi, M. (2003). Groundwater and pore water inputs to the coastal zone. Biogeochemistry 66, 3-33. doi: 10.1023/b:biog.0000006066.21240.53

Chapelle, F. H., and McMahon, P. B. (1991). Geochemistry of dissolved organic carbon in a coastal-plain aquifer. 1 . Sulfate from confining beds as an oxidant in microbial $\mathrm{CO}_{2}$ production. J. Hydrol. 127, 85-108. doi: 10.1016/0022-1694(91) 90110-4

Charette, M. A., Moore, W. S., and Burnett, W. C. (2008). "Uranium-and thoriumseries nuclides as tracers of submarine groundwater discharge," in Chapter-5 Uranium-and Thorium-Series Nuclides as Tracers of Submarine Groundwater Discharge. U-Th Series Nuclides in Aquatic Systems, eds S. Krishnaswami and J. Kirk Cochran (Oxford: Elsevier).

Charette, M. A., and Sholkovitz, E. R. (2002). Oxidative precipitation of groundwater-derived ferrous iron in the subterranean estuary of a coastal bay. Geophys. Res. Lett. 29, 1444-1447. doi: 10.1029/2001GL014512 
Chen, X., Deng, W., Wei, G., and McCulloch, M. (2020). Terrestrial signature in coral $\mathrm{Ba} / \mathrm{Ca}, \delta^{18} \mathrm{O}$, and $\delta^{13} \mathrm{C}$ records from a macrotide-dominated nearshore reef environment, Kimberley region of northwestern Australia. J. Geophys. Res. Biogeoscie. 125, e2019JG005394. doi: 10.1029/2019JG00 5394

Conley, D. J., Kaas, H., Møhlenberg, F., Rasmussen, B., and Windolf, J. (2000). Characteristics of Danish Estuaries. Estuaries 23, 820-837. doi: 10.2307/ 1353000

Crotwell, A. M., and Moore, W. S. (2003). Nutrient and Radium Fluxes from Submarine Groundwater Discharge to Port Royal Sound, South Carolina. Aqu. Geochem. 9, 191-208. doi: 10.1023/b:aqua.0000022954.89019.c9

Degenhardt, J., Dlugosch, L., Ahrens, J., Beck, M., Waska, H., and Engelen, B. (2020). Seasonal dynamics of microbial diversity at a sandy high energy beach reveal a resilient core community. Front. Mar. Sci. 7:573570. doi: 10.3389/fmars. 2020.573570

Duque, C., Michael, H. A., and Wilson, A. M. (2020). The subterranean estuary: technical term, simple analogy, or source of confusion? Water Resour. Res. 56:e2019WR026554. doi: 10.1029/2019WR026554

Duxbury, A. C. (1977). The earth and its oceans. Maryland: Addison-Wesley Publishing Co

Erler, D. V., Farid, H. T., Glaze, T. D., Carlson-Perret, N. L., and Lough, J. M. (2020). Coral skeletons reveal the history of nitrogen cycling in the coastal Great Barrier Reef. Nat. Commun. 11:1500. doi: 10.1038/s41467-020-15278-w

Erler, D. V., Shepherd, B. O., Linsley, B. K., Lough, J. M., and Cantin, N. E. (2018). Coral skeletons record increasing agriculture-related groundwater nitrogen inputs to a South Pacific reef over the past century. Geophys. Res. Lett. 45, 8370-8378. doi: 10.1029/2018GL078656

George, C., Moore, W. S., White, S. M., Smoak, E., Joye, S. B., and Wilson, A. M. (2020). A new mechanism for submarine groundwater discharge from continental shelves. Water Resour. Res. 56:e2019WR026866. doi: 10.1029/ 2019WR026866

Hansen, J., Sato, M., Hearty, P., Ruedy, R., Kelley, M., Masson-Delmotte, V., et al. (2016). Ice melt, sea level rise and superstorms: evidence from paleoclimate data, climate modeling, and modern observations that $2^{\circ} \mathrm{C}$ global warming could be dangerous. Atmos. Chem. Phys. 16, 3761-3812. doi: 10.5194/acp-163761-2016

Horta-Puga, G., and Carriquiry, J. D. (2012). Coral Ba/Ca molar ratios as a proxy of precipitation in the northern Yucatan Peninsula, Mexico. App. Geochem. 27, 1579-1586. doi: 10.1016/j.apgeochem.2012.05.008

Hsieh, Y.-T., and Henderson, G. M. (2011). Precise measurement of ${ }^{228} \mathrm{Ra} /{ }^{226} \mathrm{Ra}$ ratios and Ra concentrations in seawater samples by multi-collector ICP mass spectrometry. J. Anal. At. Spectrom. 26, 1338-1346. doi: 10.1039/clja10013k

Hu, C., Muller-Karger, F. E., and Swarzenski, P. W. (2006). Hurricanes, submarine groundwater discharge, and Florida's red tides. Geophys. Res. Lett. 33:L11601. doi: 10.1029/2005GL025449

Hwang, D. W., Kim, G., Lee, Y. W., and Yang, H. S. (2005). Estimating submarine inputs of groundwater and nutrients to a coastal bay using radium isotopes. Mar. Chem. 96, 61-71. doi: 10.1016/j.marchem.2004.11.002

Integrated Ocean Drilling Program [IODP] (2020). Integrated Ocean Drilling Program. Available online at: http://publications.iodp.org/proceedings/313/ 103/103_t9.htm. [accessed on Aug 30, 2020]

Jiang, W., Yu, K., Yinxian, S., Jian-xin, Z., Yue-xing, F., Yinghui, W., et al. (2018). Coral geochemical record of submarine groundwater discharge back to 1870 in the northern South China Sea. Paleogeogr Palaeoclimat Palaeoecol. 507, 30-38. doi: 10.1016/j.palaeo.2018.05.045

Jiao, J. J., and Post, V. (2019). Coastal Hydrogeology. Cambridge: Cambridge University Press.

Johnson, A. G., Glenn, C. R., Burnett, W. C., Peterson, R. N., and Lucey, P. G. (2008). Aerial infrared imaging reveals large nutrient-rich groundwater inputs to the ocean. Geophys. Res. Lett. 35:L15606. doi: 10.1029/2008GL034574

Joiner, C. N. (1991). Chloride concentrations in the upper water-bearing zone of the Upper Floridan aquifer in the Brunswick area, Georgia, October-November 1990. Reston, VA: U.S. Geological Survey. 91-174.

Joye, S. B., and Kostka, J. E. (2020). Microbial Genomics of the Global Ocean System. American Academy of Microbiology. Colloquium Report. Washington, DC: American Geophysical Union.

Konikow, L. F. (2011). Contribution of global groundwater depletion since 1900 to sea-level rise. Geophys. Res. Lett. 38:L17401.
Lee, Y. W., Hwang, D. W., Kim, G., Lee, W. C., and Oh, H. T. (2009). Nutrient inputs from submarine groundwater discharge (SGD) in Masan Bay, an embayment surrounded by heavily industrialized cities. Korea. Sci. Total Environ. 407, 3181-3188. doi: 10.1016/j.scitotenv.2008.04.013

Luo, X., Jiao, J. J., Moore, W. S., Cherry, J. A., Wang, Y., and Liu, K. (2018). Significant chemical fluxes from natural terrestrial groundwater rival anthropogenic and fluvial input in a large-river deltaic estuary. Water Res. 144, 603-615. doi: 10.1016/j.watres.2018.07.004

Martens, C. S., Berner, R. A., and Rosenfield, J. K. (1978). Interstitial water chemistry of anoxic Long Island Sound sediments. 2. Nutrient regeneration and phosphate removal. Limnol. Oceanog. 23, 605-617. doi: 10.4319/lo.1978.23.4. 0605

McAllister, S. M., Barnett, J. M., Heiss, J. W., Findlay, A. J., MacDonald, D. J., Dow, C. L., et al. (2015). Dynamic hydrologic and biogeochemical processes drive microbially enhanced iron and sulfur cycling within the intertidal mixing zone of a beach aquifer. Limnol. Oceanogr. 60, 329-345. doi: 10.1002/lno.10029

Michael, H. A., Mulligan, A. E., and Harvey, C. F. (2005). Seasonal oscillations in water exchange between aquifer and the coastal ocean. Nature 436, 1145-1148. doi: $10.1038 /$ nature 03935

Moore, W. S. (1996). Large groundwater inputs to coastal waters revealed by ${ }^{226} \mathrm{Ra}$ enrichments. Nature 380, 612-614. doi: 10.1038/380612a0

Moore, W. S. (1999). The subterranean estuary: a reaction zone of ground water and sea water. Mar. Chem. 65, 111-126. doi: 10.1016/s0304-4203(99)00014-6

Moore, W. S. (2010). The Effect of Submarine Groundwater Discharge on the Ocean. Ann Rev. Mar. Sci. 2, 345-374.

Moore, W. S., Beck, M., Reidel, T., van der Loeff, M., Dellwig, O., Shaw, T. J., et al. (2011). Radium-based pore water fluxes of silica, alkalinity, manganese, DOC, and uranium: a decade of studies in the German Wadden Sea. Geochim. Cosmochim. Acta. 75, 6535-6555. doi: 10.1016/j.gca.2011.08.037

Moore, W. S., Blanton, J. O., and Joye, S. B. (2006). Estimates of Flushing Times, Submarine Groundwater Discharge, and Nutrient Fluxes to Okatee River, South Carolina. J. Geophys. Res. 111:C09006. doi: 10.1029/2005JC003041

Moore, W. S., Krest, J., Taylor, G., Roggenstein, E., Joye, S., and Lee, R. (2002). Thermal evidence of water exchange through a coastal aquifer: implications for nutrient fluxes. Geophys. Res. Lett. 29:1704. doi: 10.1029/2002GL014923

Moore, W. S., and Wilson, A. M. (2005). Advective flow through the upper continental shelf driven by storms, buoyancy, and submarine groundwater discharge. Earth Planet. Sci. Lett. 235, 564-576. doi: 10.1016/j.epsl.2005.04.043

Mountain, G., Proust, J.-N., McInroy, D., and Cotterill, C. (2010). “Proc. IODP, 313 : Tokyo," in Proceedings of the Integrated Ocean Drilling Program, eds, D. A. V. Stow, F.J. Hernández-Molina, C.A. Alvarez Zarikian, (Tokyo: Integrated Ocean Drilling Program Management International, Inc).

Peterson, R. N., Moore, W. S., Chappel, S. L., Viso, R. F., Libes, S. M., and Peterson, L. E. (2016). A New Perspective on Coastal Hypoxia: the Role of Saline Groundwater. Mar. Chem. 179, 1-11. doi: 10.1016/j.marchem.2015.12.005

Portnov, A., Smith, A. J., Mienert, J., Cherkashov, G., Rekant, P., Semenov, P., et al. (2013). Offshore permafrost decay and massive seabed methane escape in water depths $>20 \mathrm{~m}$ at the South Kara Sea shelf. Geophys. Res. Lett. 40, 3962-3967. doi: $10.1002 /$ grl.50735

Porubsky, W. P., Weston, N. B., Moore, W. S., Ruppel, C., and Joye, S. B. (2014). Dynamics of groundwater discharge and associated fluxes of dissolved nutrients, carbon, and trace gases to the coastal zone (Okatee River estuary, South Carolina). Geochim. Cosmochim. Acta. 131, 81-97. doi: 10.1016/j.gca. 2013.12.030

Price, R. M., Swart, P. K., and Fourqurean, J. W. (2006). Coastal groundwater discharge - an additional source of phosphorus for the oligotrophic wetlands of the Everglades. Hydrobiologia 569, 23-36. doi: 10.1007/s10750-006-0120-5

Pritchard, D. W. (1967). "What is an estuary: Physical viewpoint," in Estuaries, ed. G. H. Lauff (Washington: DC Pub).

Qi, S.-Z., and Qui, Q.-L. (2011). Environmental hazard from saltwater intrusion in the Laizhou Gulf, Shandong Province of China. Nat. Hazards 56, 563-566. doi: 10.1007/s11069-010-9686-3

Riedel, T., Lettmann, K., Schnetger, B., Beck, M., and Brumsack, H.-J. (2011). Rates of trace metal and nutrient diagenesis in an intertidal creek bank. Geochim. Cosmochim. Acta. 75, 134-147. doi: 10.1016/j.gca.2010.09.040

Robinson, C., Li, L., and Barry, D. A. (2007). Effect of tidal forcing on a subterranean estuary. Adv. Water Resor. 30, 851-865. doi: 10.1016/j.advwatres. 2006.07.006 
Rocha, C., Robinson, C. E., Santos, I. R., Waska, H., Michael, H. A., and Bokuniewicz, H. J. (2021). A place for subterranean estuaries in the coastal zone. Estuar. Coast. Shelf Sci. 250:107167. doi: 10.1016/j.ecss.2021.107167

Rogers, D. R., and Casciotti, K. L. (2010). Abundance and diversity of archaeal ammonia oxidizers in a coastal groundwater system. Appl. Environ. Microbiol. 76, 7938-7948. doi: 10.1128/aem.02056-09

Roy, M., Martin, J. B., Cherrier, J., Cable, J. E., and Smith, C. G. (2010). Influence of sea level rise on iron diagenesis in an east Florida subterranean estuary. Geochim. Cosmochim. Acta 74, 5560-5573. doi: 10.1016/j.gca.2010.07.007

Saegar, D. A. (2012). "Introduction to Ocean Sciences, 4th edition," in Creative Commons, 444 Castro Street, Suite 900, Mountain View, (California: Ever Green).

Sáenz, J. P., Hopmans, E. C., Rogers, D., Henderson, P. B., Charette, M. A., Schouten, S., et al. (2012). Distribution of anaerobic ammonia-oxidizing bacteria in a subterranean estuary. Mar. Chem. 13, 7-13. doi: 10.1016/j. marchem.2012.04.004

Santoro, A. E., Boehm, A. B., and Francis, C. A. (2006). Denitrifier community composition along a nitrate and salinity gradient in a coastal aquifer. Appl. Environ. Microbiol. 72, 2102-2109. doi: 10.1128/aem.72.3.2102-2109. 2006

Santoro, A. E., Francis, C. A., De Sieyes, N. R., and Boehm, A. B. (2008). Shifts in the relative abundance of ammonia-oxidizing bacteria and archaea across physicochemical gradients in a subterranean estuary. Environ. Microbiol. 10, 1068-1079. doi: 10.1111/j.1462-2920.2007.01547.x

Schultz, E. A., and Simmons, H. B. (1957). Fresh Water-Salt Density Currents, A Major Cause of Siltation in Estuaries. US Army Corps of Engineers Technical Bulletin No. 2

Schutte, C. A., Moore, W. S., Wilson, A. M., and Joye, S. B. (2020). Groundwater-driven methane export reduces salt marsh blue carbon potential. Glob. Biogeochem. Cycl. 34:e2020GB006587. doi: 10.1029/2020GB0 06587

Schutte, C. A., Wilson, A. M., Evans, T., Moore, W. S., and Joye, S. B. (2016). Methanotrophy controls groundwater methane export from a barrier island. Geochim. Cosmochim. Acta. 179, 242-256. doi: 10.1016/j.gca.2016.01.022

Segarra, K. E. A., Comerford, C., Slaughter, J., and Joye, S. B. (2013). Impact of electron acceptor availability on the anaerobic oxidation of methane in coastal freshwater and marine sediments. Geochim. Cosmochim. Acta. 115, 15-30. doi: 10.1016/j.gca.2013.03.029

Shakhova, N., Semiletov, I., Salyuk, A., Yusupov, V., Kosmach, D., and Gustafsson, O. * (2010). Extensive Methane Venting to the Atmosphere from Sediments of the East Siberian Arctic Shelf. Science 327, 1246-1250. doi: 10.1126/science. 1182221

Shaw, T. J., Moore, W. S., Kloepfer, J., and Sochaski, M. A. (1998). The flux of barium to the coastal waters of the southeastern United States: the importance of submarine groundwater discharge. Geochim. Cosmochim. Acta. 62, 30473052. doi: 10.1016/s0016-7037(98)00218-x

Sivan, O., Yechieli, Y., Herut, B., and Lazair, B. (2005). Geochemical evolution and timescale of seawater intrusion into the coastal aquifer of Israel. Geochim. Cosmochim. Acta. 69, 579-592. doi: 10.1016/j.gca.2004. 07.023

Tamborski, J. J., Cochran, J. K., Bokuniewicz, H., Heilbrun, C., Garcia-Orellana, J., Rodellas, V., et al. (2020). Radium mass balance sensitivity analysis for submarine groundwater discharge estimation in semi-enclosed basins: the case study of Long Island Sound. Front. Environ. Sci. 8:108. doi: 10.3389/FENVS. 2020.00108

Tan, E., Wang, G., Moore, W. S., Li, Q., and Dai, M. (2018). Shelf-Scale Submarine Groundwater Discharge in the Northern South China Sea and East China Sea and its Geochemical Impacts. J. Geophys. Res. Oceans 123, 2997-3013. doi: $10.1029 / 2017 \mathrm{jc} 013405$
Taniguchi, M., Ishitobi, T., and Shimada, J. (2006). Dynamics of submarine groundwater discharge and freshwater-seawater interface. J. Geophys. Res. 111:C01008. doi: 10.1029/2005JC00292

Tse, K. C., and Jiao, J. J. (2008). Estimation of submarine groundwater discharge in Plover Cove, Tolo Harbour, Hong Kong by222 Rn. Mar. Chem. 111, 160-170. doi: 10.1016/j.marchem.2008.04.012

van Geldern, R., Hayashi, T., Böttcher, M. E., Mottl, M. J., Barth, J. A. C., and Stadler, S. (2013). Stable isotope geochemistry of pore waters and marine sediments from the New Jersey shelf: methane formation and fluid origin. Geosphere 9, 96-112. doi: 10.1130/GES00859.1

Wahl, T., Calafat, F. M., and Luther, M. E. (2014). Rapid changes in the seasonal sea level cycle along the US Gulf coast from the late 20th century. Geophys. Res. Lett. 41, 491-498. doi: 10.1002/2013gl058777

Wait, R. L., and Gregg, D. O. (1973). "Hydrology and chloride contamination of the principal artesian aquifer in Glynn County, Georgia," in GA Geol. Survey Hydrologic Report* 1, (Atlanta, GA: USGS).

Wang, Y. J., and Jiao, J. J. (2012). Origin of groundwater salinity and hydrogeochemical processes in the confined Quaternary aquifer of the Pearl River Delta. China. J. Hydrol. 43, 112-124. doi: 10.1016/j.jhydrol.2012. 03.008

Werner, A. D., Bakker, M., Post, V. E. A., Vandenbohede, A., Lu, C., Ataie-Ashtiani, B., et al. (2013). Seawater intrusion processes, investigation and management: recent advances and future challenges. Adv. Water Resour. 51, 3-26. doi: 10.1016/j.advwatres.2012.03.004

Werner, A. D., and Simmons, C. T. (2009). Impact of Sea-Level Rise on Sea Water Intrusion in Coastal Aquifers. Ground Water 47, 197-204. doi: 10.1111/j.17456584.2008.00535.x

Weston, N. B., Porubsky, W., Samarkin, V., Erickson, M., MacAvoy, S., and Joye, S. (2006b). Porewater stoichiometry of terminal metabolic products, sulfate, and dissolved organic carbon and nitrogen in estuarine intertidal creek-bank sediments. Biogeochemistry 77, 375-408. doi: 10.1007/s10533-0051640-1

Weston, N. B., Dixon, R., and Joye, S. B. (2006a). Microbial and geochemical ramifications of salinity intrusion into tidal freshwater sediments. J. Geophys. Res. Biogeosci. 111:G01009.

Wilson, A. M., Moore, W. S., Joye, S. B., Anderson, J. L., and Schutte, C. A. (2011). Storm-driven groundwater flow in a salt marsh. Water Resour. Res. 47:W02535.

$\mathrm{Xu}$, J., Shi, B., and Cheng, X. (2002). Study on major ecological environment problems and its survey method. Shandong Geol. 18, 95-99.

Yaala, H. B., Fniter, R., Fouchera, D., and Clarisse, O. (2019). Direct analysis of radium-226 in sediment by ICP-MS: an analytical challenge? J. Anal. At. Spectrom 34, 1597-1605. doi: 10.1039/c9ja00156e

Young, M. B., Gonneea, M. E., Fong, D. A., Moore, W. S., Herrera-Silveira, J., and Paytan, A. (2008). Characterizing sources of groundwater to a tropical coastal lagoon in a karstic area using radium isotopes and water chemistry. Mar. Chem. 109, 377-394. doi: 10.1016/j.marchem.2007.07.010

Younger, P. L. (1996). Submarine groundwater discharge. Nature 382, $121-122$.

Conflict of Interest: The authors declare that the research was conducted in the absence of any commercial or financial relationships that could be construed as a potential conflict of interest.

Copyright (c) 2021 Moore and Joye. This is an open-access article distributed under the terms of the Creative Commons Attribution License (CC BY). The use, distribution or reproduction in other forums is permitted, provided the original author(s) and the copyright owner(s) are credited and that the original publication in this journal is cited, in accordance with accepted academic practice. No use, distribution or reproduction is permitted which does not comply with these terms. 